\title{
Гуль Олександра,
}

Київський університет імені Бориса Грінченка (Київ, Україна)

ORCID ID 0000-0003-0170-8150

e-mail: sandy84@ukr.net

Брачкі Артур,

Київський університет імені Бориса Грінченка (Київ, Україна)

ORCID ID 0000-0002-8327-0468

e-mail: asbracki@wp.pl

https://doi.org/10.28925/2412-2475.2021.17.3

\section{РОСЛИННИЙ КОМПОНЕНТ ЯК СКЛАДНИК ДУХОВНОСТІ ВІРИ ВОВК: САМОІДЕНТИФІКАЦІЯ В КОНТЕКСТІ ТВОРЧОСТІ}

У статті аналізується постать Віри Вовк та духовність мисткині крізь призму ї̈ еміграційної лірики, а також висвітлюється самоідентифікація та громадська позиція авторки в текстах публіцистики, на прикладі інтерв'ю. Дослідження проводиться в двох паралельних площинах: щодо лірики, в якій увага зосереджена на духовності та апеляції до релігії, в синергії з рослинними образами та мотивами як унікальними засобами увиразнення лірики; а також щодо інтерв'ю, в якому акценти зроблено на самоідентифікації Віри Вовк. У ході аналізу ці площини тісно переплітаються, адже ідентифікацію поетки презентовано з позиціїії ставлення до вибору української мови для написання лірики, вибору топонімів уліриці, які є питомими саме для України, а також у частотному вжитку українських народних рослинних образів і мотивів. Духовність Віри Вовк унікальна, вона є вмістилищем протилежних сакральних категорій і релігійних уявлень у поєднанні з філософією і міфом. Так, в ліриці авторка звертається до Бога і постає щирою вірянкою та богобоязливою людиною, водночас залучає язичницькі уявлення праукраїнців щодо божественної сили рослинного світу. Світогляд Віри Вовк є багатовимірним, а полярність духовних складників продиктована вихованням і життєвими перипетіями мисткині, а такожії власними потребами у спілкуванні з природою і поверненні до природних первнів. Висловлюючи власну громадянську позицію, самоідентифікацію і вибір мови в рамках літературних вечорів, конференцій, круглих столів, інтерв'ю, Віра Вовк дає настанови молодому поколінню літераторів щодо використання власне українських образів, сюжетів, історичного підгрунтя нашої Батьківщини, оминаючи залучення заокеанських мотивів і стилю.

Важливим питанням у дослідженні є візії «кульгавості» українського тексту. Віра Вовк повсякчас наголошує на ролі власне українського авторського стилю у контексті формування молодого літератора. У статті ми прагнемо показати Віру Вовк як витончену душевну людину, чиє літературне коріння проростає з української землі, вбирає весь колорит української ментальності, світогляду і виливається в ї̈ творчості.

Матеріалами аналізу є поезія Віри Вовк та уривки текстів публіцистики, що ілюструють самоідентифікацію мисткині.

Ключові слова: самоідентифікація, Віра Вовк, духовний світ, сакральна площина, Нью-Йоркське угруповання, флористична символіка, рослинний компонент.

Вступ. Світогляд митця, життєві візії та переконання найбільшою мірою розкриваються крізь призму дешифрування тексту. У нашій статті таким текстом виступає еміграиійна лірика яскравої представниці Нью-Йоркського угруповання - Віри Вовк. Життєпис мисткині лишається на поверхні розуміння іiі внутрішнього світу і $€$ проєкцією профанного буття поетки, сакральне прочитується в низці образів, сюжетів, алюзій, паралелей.

Критичну перцепцію біографії «нью-йоркців», їхніх творчих пошуків, ідеології пітературного угруповання та аналіз творчого доробку висвітлено у працях на кшталт: монографії Тадея Карабовича «Міфопоетика Нью-Йоркської групи» (2017), антології Марії Ревакович 
«Нью-Йоркська група: Антологія поезії, прози та есеїстики» (2012), Юрія Коваліва «Поети Нью-Йоркської групи. Антологія» (2007), Романа Бабовала «Віртуальна антологія поезії Нью-Йоркської групи» (2002-2003).

Суб'єктивна думка літературного критика пропонує читачеві певний образ митця, за яким закріпилися чіткі прототипи: еміграційний поет, дисидент, поет в екзилі, поет-вигнанець, поет авангардизму. На грунті прототипів переважно вибудовується дослідження і перцепція поета. У даній статті ми спробуємо проаналізувати те, що приховано у слові, в думках митця, те, що прочитується між рядками, - самовираження, Я-концепція, духовність, вплив довколишнього світу і оточення.

Так, релігійна, філософська і пейзажна лірика Віри Вовк віддзеркалює низку життєвих колізій та еміграційних мандрів поетки у прихистку української митрополії, а згодом за кордоном у середовищі духовенства. У даному аспекті значний вплив на світогляд мисткині справило тривале проживання родини в еміграції при жіночому монастирі, навчання в монастирській школі. Духовними наставниками і вчителями авторки були служителі української митрополії, які завжди підтримували юну поетку «в екзилі».

Питання духовності Віри Вовк, впливу релігії на ії творчість, захоплення містицизмом, детально досліджене у працях Ю. Григорчук «Проза Віри Вовк: виміри сакрального» (2016), В. Мацько «Творчість Віри Вовк в ореолі сакрального і літературознавчого штибу» (2016), О. Смольницької «Міф про вічне повернення у поезії Віри Вовк» (2016). Самі члени угруповання завжди наголошували на щирій вірі в Бога та виключній інтуїції, які простежували у своєї колежанки.

Постать мисткині є однією з найколоритніших серед представників поетичної когорти. Спершу не визнана в Україні, а з 1990-х років не лише шанована далеко за межами Батьківщини, але й бажана гостя на літературних вечорах при Київському національному університеті ім. Тараса Шевченка, Спілці літераторів України. Завдяки своєму багатому внутрішньому світу, багатогранності ліричної спадщини, відкритості й готовності до діалогу вона $є$ однією з найбільш цитованих мисткинь у царині сучасної української літератури.

У цьому дослідженні ми проаналізуємо, зокрема, оточення мисткині як основу їі натхнення та ідейного спрямування, а також виокремимо підгрунтя для формування виключно української ментальності авторки та ії ідентифікації з Україною.
Всі виміри дослідження, прописані у статті, мають на меті не лише розказати про духовність та ідентифікацію поетки, але й наголосити на незламності людини та їі життєвих переконань, на оптимізмі та позитивному мисленні, до якого закликає поетка наступні покоління літераторів. Вона не лишає місця невизначеності людини в житті, депресивним настроям, а перебуваючи в еміграції, навпаки, своїм прикладом вказує юним літераторам шлях до формування новітньої української літератури, яка, стираючи межі правил та норм віршування, поєднуючи різні літературні напрямки, не втрачає власної самобутності, духовності, сакральності та культурного коду української нації. Незважаючи на формування Віри Вовк як літераторки в еміграційному просторі, а також їі шанобливе ставлення до творчості корифеїв світової літератури (Р. Рільке, П. Клоделя, Ш. Бодлера, В. Вітмена), захоплення ідеями західної філософії (Г.-О. Марселя, К. Ясперса, К. Ріделя), домінантою ії творчості $є$ виключно проукраїнське спрямування, прищеплене настановами митрополита і друга родини Андрея Шептицького, матір'ю Стефанією Селянською, навіяне прочитанням поезії П. Тичини, поезії та прози Г. Сковороди, захопленням творчістю М. Коцюбинського, Лесі Українки, I. Франка, В. Стефаника.

Об'єктом дослідження є еміграційна лірика Віри Вовк, а також тексти публіцистики (зокрема, інтерв'ю). Предметом дослідження $\epsilon$ самоідентифікація Віри Вовк як винятково української поетки, духовний складник творчості та рослинні образи і мотиви, що пронизують концепти ідентифікації та духовності мисткині.

Метою розвідки $є$ аналіз самоідентифікації поетки, а також визначення ролі рослинних вкраплень в еміграційній ліриці Віри Вовк. Мета статті передбачає вирішення таких завдань: аналіз ідентифікації поетки у питаннях вибору мови, образів і символів, що пов'язують iii з Батьківщиною; дослідження духовності, містицизму і сакральності лірики; виокремлення найчастотніших рослинних образів, що пронизують поезію Віри Вовк.

У ході дослідження ми вдалися до методу психологічного аналізу в контексті розуміння світогляду, духовного складника та переживань авторки, до біографічного методу для розгляду впливу життєвих колізій на формування лірики і світогляду авторки, а також культурологічного методу для аналізу топонімів, вибірковості народних рослинних символів, порівняльного - в аспекті вибору мови та самоідентифікації Віри Вовк. 
У статті ми неодноразово звертатимемося до цитування уривків лірики Віри Вовк, а також апелюватимемо до ії висловлювань в рамках інтерв'ю, конференцій задля увиразнення шляху самоідентифікації на грунті особистих міркувань авторки.

Виклад основного матеріалу. Віра Вовк (справжнє ім'я - Віра Остапівна Селянська, нар. 2 січня 1926 р.) - одна із представниць угруповання нью-йоркських поетів, яка без примусу i остраху писала українською мовою поезію, сповнену любові і співчуття до Батьківщини. Перебуваючи в еміграційному просторі, авторка не полишила свої інтенції писати рідною мовою про найпотаємніше (інтимна лірика), про найболючіше (патріотична лірика) і про святе (релігійна та пейзажна лірика, сповнена духовності, містики та міфологічних сюжетів).

У численних виступах та інтерв'ю Віри Вовк простежується співчуття українському народові в усіх буденних і політичних перипетіях та революціях. Вона не ухиляється від гострих питань, що стосуються України, чітко висловлює власну позицію, проте ії внутрішній світ більш витончений, вишуканий і гармонійний, ніж та бурхлива поверхня, яку нам показує багатогранна поетка. Так, в одному з інтерв'ю, вона відповідає на питання щодо проблем рідного міста Борислава: «Моя мала Батьківщзна болить мені. Якщ,о влада не дбає про неі, треба шукати розв'язки власними силами: иукати спільництва і орієнтациї від тих країн, де $\epsilon$ тотожні проблеми... Я родом з Борислава, але жила на Гуиульщині. Борис Левицький характеризував Черемошем мою вдачу...» [3]. В іiі словах прочитується загартована життям, зріла людина з оптимістичною щасливою вдачею, яка шукає шляхів вирішення проблеми.

Батьківщина і рідна мова - це ті питання, які мисткиня навмисне порушує, вболіваючи за долю новітньої української літератури та наголошуючи на власній ідентифікації з Україною. На думку Віри Вовк, митець-новатор має володіти рідною мовою, знати і поважати свою історію, творити в національному руслі та брати за окрасу силу українського слова, безвідносно до заокеанських сюжетів і образів творити нову історію України, а разом з тим продовжувати писати історію новітньої української літератури: «...треба бути украӥнцем $і$ поширювати наші типові прикмети. Тільки типово украӥнське зацікавить світ. Нічого іншого не треба. Не варто імітувати» [4].

Про виключно українську самоідентифікацію свідчить і низка топонімічних конкретизаторів, до яких постійно звертається Віра Вовк у своїй поезіі: Карпати, Київ, Борислав, Львів. Н. Грицик у статті «Ключові образи у поезії Віри Вовк» не обмежується лише аналізом топонімічних конкретизаторів, а навіть занурюється глибше, обираючи для дослідження частотність використання назв міст і селищ України з оспівуванням природної краси. Тут ми зустрічаємо «естетично модифіковані назви», як-от: Вижниця, Глибокі Доли, Іржавець, Зарваниці, рідний Тюдів, старее Підзамчя, - і цей перелік можна продовжувати [8].

Самоідентифікація Віри Вовк чітко простежується у виборі мови для власної творчості та кола наукових інтересів. Про становлення Віри Вовк як виключно україномовної авторки і прагнення писати рідною мовою свідчить iii виступ: «Виключно украӥнською! Щоправда, рік тому видала три повісті португальською. Але иее був обов'язок. Мене дуже довго вмовляли бразильські друзі: "Як ие так, пишеш українською - але ж живеш у Бразиліі!" Тож спровокували...» [4].

Так, Віра Вовк, щиро зацікавлена долею новітньої української літератури межі XX-XXI ст., проявляє неабиякий інтерес до новаторства в поетичному і прозовому стилі, що є непохитним під тиском і нашаруванням прозахідних поетичних течій, але не псує виключно українського колориту лірики: «Надаю перевагу класичній украӥнській тітературі й новаторам 90-х. Умене вийшла невеличка збірка “Лоза", де зібрано твори украӥнських поетів, що народилися після 1960 року. Це небагато. Перекладаю тільки те, що подобається. У молодій українській поезї багато иікавого й своєрідного, але не бракує й імітацій. Молоді поети часто прагнуть наслідувати Захід і перебирають далеко не найцікавіше. Це не дуже добре, бо иі тексти забудуться. Залишиться тільки оригінальне. Бо коли починаєщ імітувати чужу літературу, текст "кульгає"» [4].

Запорукою відсутності «кульгавості» тексту $€$ насамперед написання лірики українською мовою без залучення запозичень або ж вироблення власного авторського стилю українського митця, що поєднує інтернаціоналізми, іншомовні запозичення, суржик, діалектну мову зі стандартом правопису української мови, а не сліпе наслідування або пародіювання вільного авангардного i неокласичного чи неоромантичного американського та європейського стилів. Проте самоідентифікація поетки формується на тлі географічної детермінанти фізичного перебування. Свого часу, очолюючи кафедру германської філології в м. Ріо-де-Жанейро, Віра Вовк напише: «Тамтешня ментальність дуже схожа на украйнську. Ті самі прикметні риси, 
ті самі позитивні й негативні аспекти...» [4]. Проте це не зіпсувало ії особистого українського стилю і поетичного колориту.

Формування ментальної складової в синкретизмі двох віддалених культур вносить і додає особливої виразності творчості Віри Вовк. Поетка рішуче звертається до талановитої української молоді, що втікає словесно і сюжетно до чужих берегів: «Вважаю, що молоді українські поети дуже часто імітують Захід там, де він неиікавий, де він некорисний, де він абсолютно неоригінальний. Україна має дуже багато оригінального, дуже багато свого, й не треба відпекуватися від традицій... Наша історія, наше минуле - дуже багате, в них є чудові джерела для нових перетворень. Не доконечно шукати изього в Америці чи в Парижі» [5].

Свою ідентифікацію з Україною Віра Вовк продовжує у ліриці, де не оминає рослинних вкраплень. Принагідно зауважимо, що вибірковість рослинних образів, вплетених у громадянську, пейзажну та інтимну лірику мисткині підкреслює іiі ідентифікацію з Україною, адже Віра Вовк використовує назви тих рослин, що за принципом географічної детермінанти притаманні саме флорі і клімату України. Водночас зауважимо, що поетка оперує не лише рослинними вкрапленнями, притаманними українському ментальному простору, але й використовує образи, які виринають у її свідомості $з$ дитячих спогадів та інспіровані творчістю згаданих вище корифеїв української літератури.

Так, про вибір Батьківщини і про «малу Батьківщину» 3 любов'ю говорить Віра Вовк рядками поезії «Я плачу, сльози черешневі», увиразнюючи лірику образами яблунь, груш, черешні:

Чому пішла я геть від тих

Зелених яблунь, груш похилих?

Ще гагілковий спів не стих,

Чічками грають небосхили...

Пішла у світ - був рівний плай -

За сонця заходом вишневим.

О Черемоше, ти не лай,

Я плачу, сльози черешневі...

(«Я плачу, сльози черешневі» зі збірки «Зоря провідна»).

Авторка питає себе: «Чому пішла я геть від тих зелених яблунь, груш похилих?» Це питання не вимагає відповіді, а $€$ констатацією звершеного факту втрати себе, самодокору на кшталт: «Як я змогла покинути свій край...»

Далі в елегії «Матері і Лаврська дзвіниця» авторка поєднує спогади про Батьківщину та духовність, прикрашаючи лірику рослинними образами:

...Але наше сім'я не кульбаба при дорозі; Ми його бережемо...

... I по голоді

Виріс собі, несіяний, шестигранний

Колос пшениці...

- Так і ви нас не можете стерти,

Як слід на піску, бо ми - той бузок,

Той колос плодющий, та благовісна лілея.

...3 містичним обличчям

потьмянілого золота

Плете калинові вінки

(«Матері і Лаврська дзвіницяљ).

Ліричний текст мисткині сповнений метафор і паралелей із рослинною символікою. Тобто Батьківщина, ідентифікація з Україною та духовність - це первинні елементи творчості Віри Вовк, а рослинні компоненти виступають вторинними, але невід'ємними. Флористичні компоненти доповнюють поезію, вносять нові відтінки, формують певне символічне навантаження в ліриці. Так, українців Віра Вовк характеризує рядками: «Але наше сім'я не кульбаба при дорозі», пафосно й гордо заявляючи про нескореність і нездоланність нашого народу: «...ви нас не можете стерти, як слід на піску, бо ми — той бузок, той колос плодющий, та благовісна лілея...» [2].

Переходячи від ідентифікації до духовності, Віра Вовк молитвою огортає кохання в поезії «Дарунок», вплітаючи в сюжет образ троянди:

...Чи може молитися мені,

як у середньовіччі,

Коли віруючих молитви

Ставали трояндами, ризами, коронами

Для Марії і малого Iсуса?

Так, я хочу молитися Тому,

хто загорнений у сонце,

Бо молитва є звідні мости, веселки, аркади,

Що єднають коханців у чистім сузір'ї...

(«Дарунок» зі збірки «Зоря провідна»)

У вірші «Відпливають усі каравели» ми простежуємо, як «буяє космічне дерево життя». У поезії «Єва» в образах дерева життя і дерева смерті реалізоване авторське «дерево добра і зла»:

відпливають усі каравели відлітають меви-вітрила море з небом говорить сутінок напинає намет над сонними горами 
усіми світлами

буяє космічне древо життя

(«Відпливають усі каравели»).

під деревом добра і зла

мені так банно

наче на ньому я розп'ята

а я ж розп'ята

на Оріона кагачах...

(уривок $з$ поезї «єва»).

Свої духовні та релігійні переконання Віра Вовк описує словами: «Християнський Бог для мене альфа і омега». Про діалог із Богом авторка обережно розповідає в поезії «Бажання»:

...Щоб ми не ставили Богові питань,

І щоб усе було добре.

Щоб нас зустрічав удома

теплий погляд $з$ ікони,

Тихе світло червоної лямпадки,

Спокій святих і порядок вишивок

(«Бажання» зі збірки «Зоря провідна»).

Про особливе місце сакрального у світогляді мисткині розповідає Ю.М. Григорчук у праці: «Проза Віри Вовк: виміри сакрального». Автор детально описує мислення поетки і «становлення християнського світогляду письменниці», що міцно «вкорінене в архетипних пластах української ментальності й цілковито загрунтоване в духовному світі християнства» [7]. Так, на думку Ю.М. Григорчук, Віра Вовк надає особливого значення знакам Всесвіту, різного роду Божественним проявам: «Увесь життєвий шлях письменниці мовби зітканий із “таємних знаків”, непроглядних меандрів Божого Провидіння» [7]. Сама ж поетка неодноразово зізнавалась, що «все своє життя відчувала Господню руку над собою, навіть тоді, коли їі не заслуговувала» [7].

Найголовнішим проханням мисткині в розмові з Богом $€$ не дозволити втратити себе як людину чуйну, порядну і люблячу, про що промовисто говорять молитовні рядки «Трьох бажань»:

Мій Господи, з бездомним людом

Ділити всі печалі і відчути

Твоє крило над простими серцями

(«Три бажання»).

Аналізуючи самоідентифікацію і духовність Віри Вовк, ми мали змогу простежити рослинні компоненти в ліриц. Так, рослинні образи є частотними у пейзажній, інтимній ліриці авторки, можуть доповнювати міфічні сюжети поезіі, окреслювати сакральні простори в тексті:
Коли ти при мені, здається,

що стою в високому лісі;

Спокій перед слідами

й ніжна туга в колиханні верховіття,

А в мені, спираючи віддих, почуття краси -

Багато більшої, як та, що могла б обняти

вузька ваза моєї душі...

(«Любов»).

При цьому образ лісу - це символіка жіночого первня, хаосу, темряви і сплутаності. Саме образом лісу оперує Віра Вовк, рідко звертаючись до образу садy, що є символікою чоловічого первня, стабільності, світла і впорядкованості (принагідно зауважимо, що Юрій Тарнавський зазвичай описує красу жінки не в лісі, а в саду, тобто в гармоніі та поєднанні із чоловічим первнем («Жінка іде в сад»)).

На думку Віри Вовк, саме в лісі жінка наповнюється жіночою енергією та красою. При цьому авторка вміло вплітає міфічні уявлення праукраїнців у поетичний текст:

У цім лісі я була мавкою:

Танцювала в шелесті вітру

3 шииками в косах,

Малювала губи сунииями,

Світила очима барви дикого меду

Ведмедям і бджолам з дуплянки.

У цім плесі я була русалкою

3 жабуринням волосся,

Срібнолуским сміхом

І ковзькою рибою серця.

Це я тебе заманула під скелю

У чорні тенети Іреджина

( УУ

I знову рослинні вкраплення прикрашають і доповнюють думку авторки в інтимній ліриці «Прохання», де вона порівнює людину, що прагне втекти чи заховатись від кохання, із «тінню евкаліпта», де солодка втома кохання ховається за «шепотом між листям», де відволікає від приємного марева закоханості тяжка праця в полі «хлібу ячмінного».

Віра Вовк висловлює свої «три бажання», в яких просить в Бога простоти, що порівнюється із досконалою формою овоча:

Безобрисним, первинним речам

Останню форму дати - досконалу,

Мов круглий овоч, осінню налитий

(«Три бажання» зі збірки «Зоря провідна»).

3 огляду на вищенаведені ліричні рядки не можна применшувати ролі рослинних украплень у розгляді важливих тем і питань, 
яких торкається Віра Вовк, а надто особливого змісту, вкладеного мисткинею в кожен флористичний мотив.

Висновки. Доля України та щира віра в Бога стали життєвим кредо і основою лірики мисткині. Ці дві аксіологічні константи завжди спонукали творити задля блага Батьківщини. Гостро, із тоном повчання і виклику, повсякчас у ліриці звучать слова поетки, яка створила себе сама на підгрунті світової літератури у поєднанні з українським ментальним простором.

Маючи унікальні шанси вийти на новий рівень позаукраїнського письменства та доступ до унікальної світової літератури, знайомлячись із низкою літературних діячів, Віра Вовк не поступилась свого внутрішнього світу, що надихає іï творити, а надто у своїй ліриці і виступах не оминала можливості наголосити на власній ідентифікації як української автор- ки. Вона обрала українську мову як інструмент власного письменства, привносячи водночас в лірику проукраїнські акценти на кшталт топонімів українських локацій, рослинності, питомої для української землі та викоханої в «народній пам'яті».

Крізь призму поезії Віра Вовк викриває свій внутрішній світ, сповнений духовної зрілості, проукраїнського ідейного спрямування і гармонійного злиття з природою. Ми простежили, що свої сили і натхнення авторка вбирає з природних первнів, з духовного єства та зі щирої віри в Бога і в Україну.

У достатньо зрілому віці авторка продовжує обстоювати літературні традиції, закладені в історії батьківського письменства, дає настанови молодому поколінню літераторів і ключі до пошуку себе як автора у форматі творення новітньої української літератури.

\section{ДЖЕРЕЛА}

1. Астаф'єв, О. (2003). Поети Нью-Йоркської групи. Антологія. Ранок.

2. Бабовал, Р. Віртуальна антологія поезї Нью-Йоркської групи (2002-2003рр.). http://users. belgacom.net/babowal/indexnyg.htm

3. Віра Вовк відповідає на питання: http://miok.lviv.ua/?p=1561

4. Віра Вовк: Мою Шевченківську премію поглинула кредитна спілка. https://zn.ua/ukr/ART/ vira-vovk-moyu-shevchenkivsku-premiyu-poglinula-kreditna-spilka-_html

5. Віра Вовк: Лірика - то підсвідомість, щзо завжди працює. http://litakcent.com/2013/04/29/ vira-vovk-liryka-to-pidsvidomist-scho-zavzhdy-pracjuje/

6. Вовк, В. Вибірка поезій. Частина 2. http://users.belgacom.net/babowal/wowk_02.htm

7. Григорчук, Ю. (2016). Проза Віри Вовк: виміри сакрального. Брустурів: Дискурсус.

8. Грицик, Н. (2008). Ключові образи в поезії Віри Вовк. Наукові записки. Серія «Філологічна». $10,70-76$.

9. Карабович, Т. (2017). Мібопоетика Нью-Йоркської групи: монографія. Серія «Студї з украіністики». Талком.

10. Ковалів, Ю. (2007). Поети Нью-Йоркської групи. Антологія. У: Літературознавча енциклопедія. Т. 2. (с. 136, 233). ВЦ «Академія».

11. Ревакович, М., Габор, В. (упоряд.) (2012). Нью-Йоркська група: Антологія поезї, прози та есеїстики. Піраміда.

12. Украйнський центр. Література. ВіраВовк. www.ukrcenter.com/Література/Віра-Вовк/66810/ Три-бажання

\section{REFERENCES}

1. Astafiev, O. (2003). Poety Niiu-Yorkskoi Hrupy. Antolohiia [Poets of New-York Group. Anthology]. Ranok [in Ukrainian].

2. Baboval, R. (2020, September 07). Virtualna antolohia poezii Niiu-Yorlskoi Hrupy [Virtual Anthology of the New-York Group Poetry (2002-2003)]. [in Ukrainian].

http://users.belgacom.net/babowal/indexnyg.htm

3. Hryhorchuk, Yu. (2016). Prosa Viry Vovk: Vymiry sakralnoho [The Prose of Vira Vovk: sacred dimensions]. Brusturiv: Duskursus [in Ukrainian].

4. Hrytsyk, N. (2008). Kliuchovi obrazy v poezii Viry Vovk [Key Images in the Poetry of Vira Vovk]. Scientific Notes, Series "Philological”, 10, pp. 70-76 [in Ukrainian].

5. Karabovych, T. (2017). Miphopoetyka Niiu-Yorkskoi Hrupy: monographia [Mythopoetics of New-York Ggroup: monograph]. Series "Ukrainian Studies", Chief editor R. Radyshevsky, Talkom [in Ukrainian]. 
6. Kovaliv, Yu. (2007) Poety Niiu-Yorkskoi Hrupy. Antolohiia [Poets of New-York Group. Anthology]. In: Literary Encyclopedia, Volume 2, pp.136, 233, Editorial center "Academy" [in Ukrainian].

7. Revakovych, M., Gabor, V. (2012). Niiu-Yorkska Hrupa: antolohia poezii, prozy ta ese [New-York Group: Anthology of poetry, prose and esays]. Piramida [in Ukrainian].

8. Ukrainian Center. Literature. Vira Vovk. [in Ukrainian].

www.ukrcenter.com/Література/Віра-Вовк/66810/Три-бажання

9. Vovk, V. Vybirka poezii, Chastyna 2 [Selected Lyrics. Part 2] [in Ukrainian].

http://users.belgacom.net/babowal/wowk_02.htm

10. Vira Vovk vidpovidaie na pytannia [Vira Vovk Answers Questions] [in Ukrainian].

http://miok.lviv.ua/?p=1561

11. Liryka - to pidsvidomist, shcho zavzhdy pratsiuie [Lyrics as Consious that Always Works] [in Ukrainian].

http://litakcent.com/2013/04/29/vira-vovk-liryka-to-pidsvidomist-scho-zavzhdy-pracjuje/

12. Vira Vovk: moiu Shevchenkivsku premiiu pohlynula kredytna spilka [Vira Vovk: My Shevchenko Award has been Taken by the Credit Union] [in Ukrainian].

https://zn.ua/ukr/ART/vira-vovk-moyu-shevchenkivsku-premiyu-poglinula-kreditna-spilka-_html

\section{Oleksandra Hul,}

Borys Grinchenko Kyiv University (Kyiv, Ukraine)

ORCID ID 0000-0003-0170-8150

e-mail: sandy84@ukr.net

\section{Artur Bracki,}

Borys Grinchenko Kyiv University (Kyiv, Ukraine)

ORCID ID 0000-0002-8327-0468

e-mail: asbracki@wp.pl

\section{FLORAL COMPONENT AS THE ENTRY OF VIRA VOVK'S SPIRITUALITY: SELF-IDENTIFICATION WITHIN THE CONTEXT OF HER CREATIVE WORK}

The article analyses the personality of Vira Vovk and the spirituality of her emigration lyrics, as well as self-identification of the author in the publisistic texts (within the context of the interview). The study is carried out in two parallel ways: on the one hand, in lyrics, attention is focused on the spirituality of the author and appeals to religion, in synergies with plant images and motifs as unique means of lyrics; on the other hand, in the interview, the accents are made on self-identification of Vira Vovk. During the analysis, these ways are closely intertwined, because the identification is presented from the position of the choice of the Ukrainian language for writing lyrics, the choice of toponyms in the lyrics, which are specifically for Ukraine, as well as in the frequency of using Ukrainian folk plant images and motives. Spiritual faith of the poetess is unique, because it is a content of opposing sacred categories and religious representations in conjunction with philosophy and myth. So, in the lyrics, the author appeals to God, while attracting pagan presentations of the ancient Ukrainians on the Divine Force of the plant world. The worldview of Vira Vovk is multidimensional, and the polarity of spiritual components is dictated by raising and vital rejection of mysteries, as well as its own needs in communicating with nature and returning to natural roots. Expressing her own civic position, selfidentification and language choice in the framework of literary evenings, conferences, round tables, interviews, Vira Vovk gives guidance to a young generation of writers regarding the use of own Ukrainian images, plots, historical grounds of our homeland, omitting the involvement of overseas reasons and style. An important issue in the study is the usage of Ukrainian language. Vira Vovk always emphasises on the role of the Ukrainian author's style in the context of the formation of a young writer. The article is aimed at showing the poetess as a sophisticated person whose literary roots germinate deeply from the Ukrainian land, absorb the whole spectrum of Ukrainian mentality. The materials of the analysis include the poetry and interview, illustrating the self-identification of the author.

Key words: self-identification, Vira Vovk, sacred level, New-Yorkgroup, floral symbols, plant component.

Стаття надійшла до редакції 25.01.2021

Прийнято до друку 18.04.2021 